\title{
The Change Process at Schools Based on the Variables of School Administrators and Environment
}

\author{
Abdullah Balıkçı, Sait Akbaşı², Mehmet Şahin ${ }^{3, *}$, Murat Kılıç ${ }^{4}$ \\ ${ }^{1}$ Hasan Ali Yücel Faculty of Education, Istanbul University, Turkey \\ ${ }^{2}$ Faculty of Education, Hacettepe University, Turkey \\ ${ }^{3}$ Ahmet Keleşoğlu Faculty of Education, Necmettin Erbakan University, Turkey \\ ${ }^{4}$ Selçuklu Cahit Zarifoğlu Primary School, Turkey
}

Copyright $(2017$ by authors, all rights reserved. Authors agree that this article remains permanently open access under the terms of the Creative Commons Attribution License 4.0 International License

\begin{abstract}
Change is a growing phenomenon in the era we live. The issue of change has been one of the topics of interest in the field of administration. In general, change refers to transfer from the present situation to another situation and differentiation. Implementations related to the change also affect today's education systems. School administrators, primarily, can be shown responsible for the implementation of changes in educational institutions. The purpose of this research is to understand how the change in educational institutions is assessed in the school administrator and the environment context. The participants of the research are 12 administrators who are determined among the administrators of educational institutions working in the central districts of Konya province (Karatay, Meram, Selçuklu) and from different socio-economic districts and in the spring term of 2015-2016 academic year. During the publication phase, the interviews are reviewed and the participants' approval for publication is asked. This study has been carried out within the framework of phenomenological design and the qualitative case sampling is preferred among from purposeful sampling methods. In the analysis of the data, descriptive analysis technique is used. As a result of the research, it is understood that the school administrators have adopted the phenomenon of change and have taken this fact into account in their work. It is understood that making new arrangements in the existing structure will be reflected positively in the school and that the surrounding area should also be taken into consideration.
\end{abstract}

Keywords Change, School, School Administrator and Environment

\section{Introduction}

The issue of change has been one of the topics of interest in the administration literature. Especially in the ' $90 \mathrm{~s}$, "change" has entered into personal and organizational life. In general, change means bringing something from one level to another, which means not only the change of the location of the individuals and objects but also the change of the present situation of personal information, talent, etc. [1]. According to Küçükali [2], change involves all changes in a given period in an organization. For change, the organization must experience change in all its elements and in elements themselves. Change may have positive or negative results, which is an indicative for achieving the organizational goals or not. It can be stated that in respect to the attainment of organizational goals, it is a positive; if there is a change in the point of deviation from the organizational goals, it is a negative change.

Change is a process including several stages in itself. In the most general frame; change includes the stages of "initiate", "implement", and "maintain continuity" [3]. Lewin sees change as a three-stage procedure. These are melting of ice, movement and re-freezing the organization. During the stage of ice-melting, there are attempts to weaken the forces that protect the status quo. In the second stage, new values, attitudes and behaviors are developed. In the third stage, the change is stabilized and re-freezing occurs. However an effective change process includes more comprehensive and detailed activities [4], in order to experience change in an organization, there should be three conditions which are presence of respectful and influential leaders, need for a change, motivation for a change and being ready for a teamwork. According to Beycioğlu, Aslan [5], the process of change, the school should identify a strategy that can have positive outcomes for future change requests. This strategy should address factors such as co-decision, effectiveness and productivity in the school. According to Ada, Akan [6], in order to ensure a prevalent and effective teaching-learning understanding in a school, it is necessary to re-consider the education system and change the schools by taking into account the new values 
required by this age. This understanding must also be taken into the main objectives of schools at the same time. School administrators are at the forefront of education and training activities carried out in educational institutions. In addition to this, school administrators should reflect the changes to educational activities in the school appropriately, and they are expected to manage the change according to the aims of education. In educational changes generally one of these approaches are followed: first one is mainly local and includes school centered approaches; second approach is about viewing the topic from a macro perspective.

There are several ways to do this; but generally focused on issues such as school-based management, decision-making and teaching, the identification and enhancement of teachers' roles, the application of various innovations to the school, the rethinking of teacher education, the leadership of education, the sharing of school mission and objectives by teachers, administrators, parents and students [7].

The task of an administrator in a change management process is to understand how parts balance each other, how changing an element changes the others, and how ranking and speed affect the whole structure [8]. According to Çolakoğlu [9], the task of the school administrator at the point of change is to regard change as an indispensable tool for effective work at school, adopt change management and adapt it to the school. Leadership features should be adopted for this. According to Özdemir [10], one of the duties of the school administrator is to see the school as a unit of change. For this to take place change is taken into consideration in all areas of the school and the change must include all dimensions of education. To Beycioğlu, Aslan [5], the school administrator and the teachers who are expected to be conscious of change should inform other stakeholders about this issue, convince them about the planned change, and put all stakeholders into action in this direction. According to the research conducted by Aydoğan [11], administrators and teachers have a positive view of "change". The duty of the school administrator here is to convince the teachers that the change can be implemented in a healthy way in the school. He must inform them as much as he can. According to the research conducted by Töremen [12], school administrators think that change in the school is a must. For this, it is necessary to know the reasons for the organizational change and to identify the obstacles they can face in this way. What needs to be done is to educate school administrators, to develop the structures and processes for change and be open to change. According to Mintzberg [13], an entrepreneurial administrator devotes a significant part of his time in organization to seek opportunities for the change and dedicate them to the organization. What is expected from an administrator is to be an entrepreneur and give importance to communication.

School-environment cooperation is an important point in terms of education and training. The school pays attention to different people and groups when performing this function. According to Sergiovanni [14], schools include family and community members in decision-making processes together with school's learning and teaching activities, make them serve as a source for increasing school efforts and rely them on providing good public relations as well as being school advocates. Bursalıoğlu [15] considers administrators, teachers, students, other staff in schools, families and other stakeholders as influential factors in school administration. According to Şişman [16], environment and schools are inseparable parts of a whole. Separating schools from the environment may hinder the basic tasks of the school. What is expected from the school and the administrators is to open the doors of the school to the environment, namely, to be in cooperation and communication with the environment. According to a study conducted by Çalışkan [17], school administrators pay attention to participation of students' families in school activities and their contribution to the school. For this, they have a tendency to cooperate with the whole environment of the school (formal-informal).

In Turkish Education System, there are legislative provisions governing the duties of school administrators in relation to the school. These provisions are regulated in different regulations according to the degree of education and to the kind of the school. In addition, it is seen that the duties and responsibilities differ according to the content of the task (school principal, deputy head of school, etc.) in the regulations stated. Another issue that draws attention in the relevant legislation is that the provisions of the legislation are frequently changed. Some of the relevant regulations and articles are:

- Ministry of National Education Regulation on Pre-school Education and Primary Education Institutions, articles of 39-42,

- Ministry of National Education Regulation for Secondary Education Institutions (articles of 78-83)

- Ministry of National Education Special Education Services Regulation (articles 52-56)

- Ministry of National Education, Educational Institutions Social Activities Regulation (article 14.). [18].

\section{The Aim and Importance}

The purpose of this research is to find out how the change in school takes place in the context of the school administrator and the environment. Here, the school administration covers the directors and vice directors of the schools. The school environment is all around the school including the physical subjects in addition to human resources as well. From here, the following questions are asked about how the change in school is assessed by school administrators: 
- How do school administrators perceive change at schools?

- What is the relationship between the school administrators and the environment during the change process?

Putting forward the perception of change by school administrators, who have an important position at the point of conducting and directing educational activities, and their reflection on the environmental context will allow us to better understand our educational system; it is thought that the school administrators will contribute to solve the problems in the context of their duties.

\section{Method}

This section is about the studies carried out in order to achieve the purpose of the research and to obtain valid and reliable results.

\section{Research Design}

The research is designed in the phenomenological (phenomenological) framework within the qualitative approach. According to Christensen, Johnson and Turner [19], phenomenology is a qualitative research method in which the researcher tries to explain how one or more participants experience a phenomenon (event, situation, concept, etc.). Phenomenology focuses on facts that we are aware but we do not have an in-depth and detailed understanding it. [20].

\section{Participants}

Participants are 12 school administrators who are determined among the school administrators of the districts located in different socio-economic levels in the central districts of Konya province (Karatay, Meram, Selçuklu) and who work in the spring term of 2015-2016 academic year. Participants are selected from public schools. In this study, easy reachable case sampling is chosen among purposeful sampling methods and applied to the study. According to Miles and Huberman [21], an easily accessible sample provides time, money, and flexibility at the expense of the intended knowledge and reliability. The real names are not used when the views of the participants are included, instead OY1, OY2, OY $3, \ldots$ are used to describe the participants. The information about the participants is given in Table 1 .

According to the table 1, 12 school administrators are participated in the research; 10 of them are male and 2 of them are female. Out of 12 school administrators, 4 are school principals and 8 are deputy principals. Participants include 8 classroom teachers, 2 religious culture and ethics teachers, 1 social studies teacher, and 1 technology design teacher.
Table 1. Information about the participants

\begin{tabular}{|c|c|c|c|}
\hline \multicolumn{4}{|c|}{ Gender } \\
\hline \multicolumn{2}{|r|}{ Male } & \multicolumn{2}{|r|}{ Female } \\
\hline \multicolumn{2}{|r|}{10} & \multicolumn{2}{|r|}{2} \\
\hline \multicolumn{4}{|c|}{ Branch } \\
\hline $\begin{array}{l}\text { Classroom } \\
\text { Teacher }\end{array}$ & $\begin{array}{l}\text { Religious } \\
\text { Culture } \\
\text { and Ethics }\end{array}$ & $\begin{array}{c}\text { Technology } \\
\text { Design }\end{array}$ & Social Studies \\
\hline 8 & 2 & 1 & 1 \\
\hline \multicolumn{4}{|c|}{ Position } \\
\hline \multicolumn{2}{|c|}{ School Principal } & \multicolumn{2}{|c|}{ Deputy Principal } \\
\hline \multicolumn{2}{|r|}{4} & \multicolumn{2}{|r|}{8} \\
\hline
\end{tabular}

\section{Data Collection and Analysis}

The data for this study is obtained through a semi-structured interview form. After the analysis of the interviews, open coding is done and then themes are obtained from the concepts reached. According to Neuman [22], open coding is the first coding of the qualitative data; the investigator examines the data and summarizes them in preparation for analytical categories or codes. While preparing the interview form, the opinions of 2 Turkish teachers are asked to determine the appropriateness of the research questions in terms of language and narration, 2 academicians from the field are interviewed to determine technically appropriateness of the questions. The final form formed after the examinations are applied to the participants determined and volunteered to participate in the investigation. During the interview, questions are asked at the end to reveal detailed meaning.

Circumstances that are not foreseen at the beginning of the research but arouse during the research are taken into consideration. In the interview analysis report, it is aimed to provide a more comfortable conception of the readers about the research context and the essence of the work by presenting direct citations to the reader. Since it is one of the most important purposes to be able to provide this in qualitative studies, the quotations have been taken without modification and without correction. Negotiations are recorded so that data loss isn't experienced in the talks and consent of the participants is asked before the interviews. Four of the strategies Christensen and others [19], pointed out for the validity of the study are applied in this study. These strategies and their applications are as follows:

Variation: Confirmation of the negotiations is done through examination of the relevant legislative provisions besides the negotiations.

Comprehensive field study: The relevant literature has been examined while formulating the interview form.

External supervision: In every stage of the research, the views of the academicians working at the field, the opinions of language experts and the ones who could participate in the research are asked. 
Direct quote: Negotiations are recorded using voice recorder and camera so data loss is prevented.

In the analysis of the data, descriptive analysis technique is used. Şimşek and Yıldırım [20], explain the descriptive analysis as follows:

"In descriptive analysis, direct citation is frequently given in order to reflect the views of the interviewed or observed individuals in a striking way. The purpose of such analysis is to present the findings to the reader in an organized and interpreted way. The data obtained for this purpose are first described systematically and explicitly. Later these descriptions are explained and interpreted, cause-effect relationships are examined, and some results are reached (p. 224)".

The application of descriptive analysis in research is as coding the data, from which the theme and sub-themes are reached. During this analysis, the views that would not contribute to the research are not taken into account and are not included in the themes.

\section{Findings}

In this section, the themes and sub-themes created by the findings obtained, the conclusions made by the participants about these themes, quotations are given. In addition, comments on the messages desired to be given from the data-theme-quote triangle are also included in this section. The outcomes of the research are categorized under the following subtitles and details are presented with reference to the idea of the participants as the data obtained.

\section{Findings about How Change Is Perceived by the School Administrators}

Participants (school administrators) pointed to 4 sub-themes when evaluating "change" in terms of the school administration, taking into account these aspects they preferred to reveal the school administrator and change relationship. These sub-themes are the perception of change by the school administrator, the characteristics of the school administrator in the process of change, and the impacts of bureaucratic structure on the school administrator during the change.

\section{Perceived Change by School Administrators}

Participants (school administrators) are more likely to regard change with positive meanings such as keeping up with innovations and developments; for this, they prefer an approach that pays attention to technology and the qualities that the age demands. Half of the participants (6 participants) perceive change positively and assess change with development, at the same time participants correlate change with innovation. Participants also see change as a necessity for being up-to-date in all areas of life. The declared perspectives show that school administrators are ready to change, perform change at school and take this point into account in their future plans. Participants' views on the topic are as follows:

OY 1: To follow new developments in the light of science and be able to keep pace with the needs of today or our age.

OY 2: Everything in the world is changing and evolving so people also follow new developments in current affairs and move to a different position from their previous position.

OY 3: We are in a constant change, our physical appearance changes, our knowledge and experiences change and even our ethical values change so change is inevitable and very important.

OY 4: Change means keeping up with life and new developments,...

OY 5: change refers keeping pace with developments both in terms of culture, education and technology,...

OY 10: Actually, when change is mentioned, it is meant keeping pace with the conditions of the age and promoting educators,...

Participants also consider evaluating the concept of change pedagogically, reflecting on the school and students. According to them, the concept of change should be considered as development and integrated with education. With this approach to be followed, they believe it can provide benefit to the students and the school. They think that different applications must be followed and brought to the school environment for the stated benefit. The opinions are as follows:

OY 6: When change is stated, we, as educators, perceive it as the change in education primarily.

OY 7: What comes first to my mind when change is mentioned is scientific theories especially constructivist approach which promotes student-centered learning.

OY 9: I think change is about both updating oneself and offering different applications to the students. I think it's important to add educational differences.

Participants also see "change" as a fact of life, an indispensable element. They pay attention to what is happening and to reveal it with all its openness. It can be said that the participants give importance to the change as a general view of life. The opinions are as follows:

OY 3: Change is the reality of life, it is a phenomenon based on the center of life...

OY 11: Change is doing what needs to be done.

OY 12: Change refers both positivity and negativity.

\section{Characteristics of the School Administrator in the Process of Change}

At the "change" point, participants (school administrators) prefer to keep track of the human traits, leadership-based approach, flexibility, change and development as features of school administrators. It is 
understood that school principals consider both the individual and professional characteristics of the school administrator in the stated opinions. It is seen that the above-mentioned concept of change-development is also important in terms of managerial characteristics. Another remarkable point of view is the existence of a way of thinking in which the personal and professional characteristics are treated as a whole, that they are supportive of each other, and in the sense of mutual benefit both inside and outside the school. In other words, school administrator represents an empathic approach by considering himself/herself as much as s/he considers society or vice versa. This suggests that in the organizational setting the school administrator has adopted a balanced approach and reconciled personal and organizational goals. Participants' views on the subject are as follows:

OY 1: School administrator should be such a person that can follow developments closely and also follow the developments in technology so that $\mathrm{s} /$ he can keep up with the developments. Accordingly s/he can reflect these developments to the school. In terms of personal traits, s/he should have leadership and management skills; in terms of professional traits, s/he should have features to follow developments together with teachers and stakeholders..

OY 2: Technically and professionally our job is education so a school administrator has a fund of knowledge about this issue, at the same time to become a leader as an educational administrator, I believe the school administrator has knowledge and skills about his/her profession.

OY 3: Well, school administrator should be flexible in certain points and be sensitive, also $\mathrm{s} / \mathrm{he}$ will believe in the necessity of change or else $\mathrm{s} / \mathrm{he}$ cannot do what $\mathrm{s} / \mathrm{he}$ doesn't believe.

OY 4: It is about qualifications, in other words, having necessary knowledge and skills to keep pace with the age.

OY 6: It is difficult to apply change if the school administrator does not believe. So s/he needs to do some research and direct his/her team in this direction. The school administrator must have the leadership qualities, OY 7: I believe that an educator should develop himself/herself personally and professionally. But it is not just about reading books or scientific articles, for instance, $\mathrm{s} / \mathrm{he}$ can develop himself/herself about multiple intelligence program...

OY 12: The school shows development as much as the school administrator keeps pace with the change.

\section{The Impacts of Bureaucratic Structure on the School Administrator in the Process of Change}

Participants (school administrators) think that the task-responsibilities assigned to them bring negative points in the process of change in general. In the existing structure, it is believed that there is an incompatibility between what is done and what is desired, so the participants adopt the view that the changes in the applications are not like the way desired in terms of education and structure. They group their views in the following way:

- Bureaucracy is an obstacle for change.

- Frequent changes in the legislation do not help.

- Frequent changes in the existing legislative structure are accompanied with complexity and uncertainty. This situation negatively affects the school administrator in both professional and individual terms.

- They state they view the regulation about appointment and relocation of the administrators as a problem because it directly affects them.

Participants generally view the leadership approach as a solution proposal at this point where they have expressed their negative views. They think that change through a leadership approach can lead to a positive structure.

OY 1: Regulations are not motivating and there are some uncertainties. It needs to be clearer and easily understandable.

OY 2: the developments and changes in education in our country are made on a day-to-day basis, not based on a certain plan, changes that are unprepared affect people in a way.

OY 3: Within 11 years the administrative appointment regulation has changed at least 8 times.

OY 9: Regulations and legislation change very often and we cannot follow them. Instead we look at the regulations when we need to check a rule or application. However, sometimes these changes can lead to contradictory situations.

OY 11: We're tired of the legislation change now. In the past we could see the future. Nowadays change is done just for the sake of change itself. Actually constant change may result in turning back to the old version of the regulation.

OY 8: In order to create a new education system, the school principal must be both a leader and a leader in a changing and developing world. If $\mathrm{s} / \mathrm{he}$ cannot get it, there will be nothing but the classic school principal type.

\section{Findings and Interpretations about School Administrator and Stakeholder Interaction in the Process of Change}

Based on the findings from the data, 4 sub-themes are obtained. These sub-themes are; school administrator-teacher interaction in the change process, school administrator-student interaction in the change process, school administrator-parent interaction in the 
change process, school administrator - environment and other community interaction in the change process.

\section{School Administrator-Teacher Interaction in the Process of Change}

Participants (school administrators) see the teacher as the most important driving force to assist the school administrator in the process of change. Without them, the understanding of change within the school and the applications for it do not make any sense. To this end, they particularly emphasize the "cooperation" factor in their views, and they also point to elements such as transparency, facilitation, and belief in change that support this situation. In the process of change, the school administrator attaches importance to teachers and shows this by being a role model for them or being in a position to support them in their work. To make change-school administrator-teacher triangle function properly, the tangible and spiritual contributions rendered to the teacher are given importance and the necessity of it reflected in the views. It is believed that being qualified in occupational aspect is an important point and so do the teachers being qualified. It can be said that these elements are emphasized, so that they could positively be reflected to the students and the parents. Participants' views on the subject are as follows:

OY 2: one of the most important elements in this regard is the teachers and we need to get benefit from them and get their ideas.

OY 3: Teacher is the locomotive of educational institutions, you cannot ignore the teacher. It is the center of education and training activities.

OY 4: teachers are needed to attend some seminars each year to increase their motivation. Teachers need to be financially supported and the transportation problems of those working in remote areas need to be solved. Municipalities and parent-teacher associations should provide support to improve the conditions of teachers.

OY 6: instead of despotic way of administration, an understanding administration can be more successful but the administrator should have necessary boundaries in some aspects. Also school administrator should convince teachers what will be done is really necessary. OY 7: Teachers should improve themselves professionally and at least must have a master's degree. Thus, they can transfer and apply what they have learnt to the school and their students.

OY 11: No change can be possible without teachers in administration.

OY 12: Administrators should be role models for teachers on change.

\section{School Administrator-Student Interaction in Change Process}

Participants (school administrators) agree that school administrators should also take into consideration students during the school change process. Participants adopt a student-centered approach during change process in school. They support this approach and take into account that guidance is provided to students, flexibility is provided, and conditions are regulated so that they can be comforted. Another point that is noteworthy in the approaches is that the participants see the participation of the students in the school administration as favorable. Taking students' views in school administration and taking their ideas into consideration can also be regarded as a sign that a flexible, participatory management approach can be passed on. In addition, school administrators regard student-centered and participatory management as their duty. It is also thought that the school administrators are trying to adapt to the changing world and professional understanding and give importance to the socialization of the students. The opinions of participants (school administrators) about the subject are as follows:

OY 3: Now, of course, our students are actually our customers, we need to make the school a little more flexible and arrange it according to the students.

OY 4: What can we do with the students? During the administration, the individuals in the school are servants, administrators, teachers and the most important one is students. By bringing them together, it is possible to get their opinions and thoughts in their school administration to make administration more active. They can have a more active role in the administration...

OY 8: What kind of change you want, you need to make students want it too or it is necessary to analyze their needs well.

OY 9: I think it should be student-centered and priority should be students...

OY 11: It should give importance to the students' preferences during the while the work done and the decisions taken, because what is done is done for the students.

\section{School Administrator-Parents Interaction in Change Process}

Participants (school administrators) take parents into account in this process. They see them more as a means of informing about what is going on at school, getting feedback on the process and developing positive attitudes towards the school. However, it is also important to provide information to the parents as a precaution against unwanted situations. It is also pointed out that the inclusion of them in the management process is not an obstacle to management but a supportive quality. Participants understand that they are given the duty to inform parents about "the school" and to effectively incorporate them into the school, in terms of the parents in the process of change. This understanding shows that the school administrators have adopted the "open system" approach which considers the environment in school administration. Views on the subject can be listed as follows: 
OY 1: Yes, in this newly evolving or changing educational process, parents should often be informed.

OY 2: Now, as we said before, the basic components are three, but we are now a guide and the parents are very important.

OY 3: they are a kind of customer for us, but now the people who care about the future of their child should be respected. I mean, we should put them on a pedestal.

OY 6: Parents must be told that the school has a certain type of administration and certain principles, but an atmosphere should be created in which parents can make suggestions to the administration process without intervention.

OY 12: When we think that education has three important components, parents should obviously be in education. ... It is absolutely crucial that the school-parent relationship is important in both academic and educational success.

\section{School Administrator-Other Stakeholders Interaction in Change Process}

Participants (school administrators) in the process of change find it appropriate to emphasize the fact that they have also expectations from stakeholders other than parents and participants emphasize there are two points information and communication that can be done together with stakeholders. School administrators give importance to inform other stakeholders like they do with parents. They think that these informing activities can be accompanied with visits to the stakeholders. Communication with other stakeholders (the environment) is seen as important as informing activities. It is thought that open communication will contribute to the school and it will increase opportunities for cooperation with the environment. This approach is also considered to be appropriate for the "open system" approach. It is understood from the expressions that participants think both formal groups and informal groups as other stakeholders. The opinions about the subject are as follows:

OY 1: The school administrator may go to such a cooperative work with the local authorities, the various tradesmen, the municipalities, or the media, by informing them about this change and receiving all kinds of support and assistance from them.

OY 2: As I said before, while the school gives education to students, it can also cooperate with all kinds of institutions in the social environment such as the local administrators, non-governmental organizations, foundations.

OY 4: In communicating with the environment, the mayor and the local authorities may be interviewed and a education committee may be established. This committee includes the school administrators, teachers and students as well.

OY 5: Now, actually it is necessary not to interrupt the relationship with community organizations, especially with NGOs.

OY 7: For example, Selcuklu Municipality made SEDEP project which contributed education positively. That is a high quality project which gives way to new progresses. Similar projects should be done and contribution to education will be possible.

OY 10: Of course municipalities, local authorities, in some places business people and parents are really contributing to education.

\section{Other Points Included in the Research}

Participants (school administrators) are asked to highlight the point (s) they wanted to add about the research, they stated that specifically and in general the school-environment interaction should be addressed in all aspects of the school administration. Participants believe that change can evolve development with this way. It is understood that the aim is to increase the material and spiritual contributions to the school and to provide an effective and productive environment to the teachers and students. The opinions can be stated as follow:

OY 5: We need to embrace everybody. We should be at equal distance to everyone.

OY 7: The school administrator should listen to teachers, students and parents; s/he should take their view into consideration. There should be a humanistic approach so that even if what is sad isn't right, the speaker should be listened respectfully.

OY 9: Namely, I assume that democracy and participation for school are important, so I think it is necessary to ask everyone's idea for what is done.

OY 12: It shouldn't be forgotten that we can learn something from every person.

\section{Conclusions, Discussion and Suggestions}

Participants in the survey showed that they had a positive attitude towards change and that they wanted to adopt and maintain it within the school. Participants place leadership and human characteristics to forefront in the change process. Yildiz [23] research revealed that self-efficacy of school administrators in terms of managing the change, determining the need for change, implementing and evaluating the change at school is high, which support the findings of our research. It is understood that current structure is damaging to the change process instead of contributing to it and there are provisions in the system that need to be changed. Aslanargun [24] research revealed that school administrators should review the values of the society, which have lost their updated status, and after reviewing bring them into the school environment. And the school administrators see this as their duty. This result also supports our findings. It is not possible for the school administrator to progress alone in the process of change. It 
is understood that it is necessary to take into account the management processes mentioned in the literature and draw the near and distant environment to the school. An important aspect of the change process is that the needs and current conditions in the process must be well analyzed. Balıkçı [25], research revealed that to implement change in the organization, there is need to be more cooperation and communication between school administrators and teachers. According to a survey conducted by Gül [26], school administrators give importance to cooperation and partnership with the environment. According to a study by Stringer, Hourani [27], the link between the school and its families can be achieved through the school administration's efforts. For this reason, the school administration can make the necessary arrangements and provide the school's communication with the whole environment. It can be said that the researchers conducted by Balıkçı [25], Gül [26] and Stringer, Hourani [27] (2003) are consistent with the current research findings. From the findings obtained, the following suggestions can be made: the bureaucratic structure should be organized in such a way as to reveal the leadership qualities of school administrators. In order for the school administration to be successful in the process of change, the opportunities should be increased. More and different methods of school administrator-change interaction should be investigated.

\section{REFERENCES}

[1] Ada, Ş. \& Akan, D. (2007). Değişim Sürecinde Etkili Okullar, Kazım Karabekir Eğitim Fakültesi Dergisi, vol. 16, pp. 343-373.

[2] Aslanargun, E. (2012). Okul müdürlerinin sahip olmas1 gereken değerler. Kuram ve Uygulamada Eğitim Bilimleri: 12 (2) [Ek Özel Say1/ Bahar 1327-1344.

[3] Aydoğan, İ. (2007). Değişim süreci ve okul personeli. GAU J. Soc. ve Appl. Sci., 3(5), 13-24.

[4] Balıkçı, A. (2004). İlköğretim okulu yönetici ve öğretmenlerinin değişime ilişkin algısı ve değişimin eğitim açısından değerlendirilmesi (Yayınlanmamış yüksek lisans tezi). Selçuk Üniversitesi, Konya.

[5] Beycioğlu, K., Aslan, M. (2010). Okul gelişiminde temel dinamik olarak değişim ve yenileşme: okul yöneticileri ve öğretmenlerin rolleri. Yüzüncü Y1l Üniversitesi, Eğitim Fakültesi Dergisi. Haziran 2010. Cilt:VII, Sayı:I, 153-173.

[6] Bursalığlu, Z. (2000). Okul yönetiminde yeni yapı ve davranış. Ankara: PegemA.

[7] Christensen, L. B., Johnson, R. B. ve Turner, L. A. (2015). Nitel ve karma yöntem araştırmaları (M. Sever, Çev.), (A.Aypay, Çev. Ed.) Araştırma yöntemleri desen ve analiz (400-433). Ankara: An1.
[8] Çalıșkan, M.S. (2014). Etkili okul çevre ilişkisinin okul yöneticisi açısından değerlendirilmesi (Yayınlanmamış yüksek lisans tezi). Erciyes Üniversitesi, Kayseri.

[9] Çolakoğlu, M. (2005). Eğitim örgütlerinde değișim ve liderlik. Hasan Ali Yücel Eğilim Fakültesi Dergisi Sayı 1, 63-77.

[10] Duck, J.D. (1998). Değişim yönetimi, (Çev. Tüzel, M., 1999). İstanbul: MESS Yayın.

[11] Erdoğan, İ. (2002). Eğitimde değişim yönetimi. Ankara: PegemA Yayıncilik.

[12] Gül, İ. (2009). Okul yöneticilerinin liderlik yaklaşımlarının okul-çevre ilişkileri üzerinde etkisinin değerlendirilmesi (Yayınlanmamış doktora tezi). Gazi Üniversitesi, Ankara.

[13] Koçel, T. (2001). İşletme yöneticiliği. İstanbul: Beta Basım Yayım Dağıtım A.Ş.

[14] Küçükali, R. (2011). Yönetim felsefesi. Ankara: Nobel.

[15] Luecke, R. Değişimi ve geçiş dönemini yönetmek, (Çev. Şensoy, Ü., 2009). İstanbul. Türkiye İş Bankası Yayınları.

[16] Harvard Bussiness Essentials (2017). Managers Handbook. Manager's Toolkit the 13 Skills Managers Need to Succeed. Harward Business Press. (Çev. Şensoy, Ü., 2017). 4. Basım, İstanbul. Türkiye İş Bankası Yayınları.

[17] Miles, M. B., Huberman A. M. (2015). Veri toplamaya odaklanmak ve veri toplamayı sinırlamak: anlamlı bir başlangıç (D. Örücü, Çev.), (S. Akbaba Altun, A. Ersoy, Çev. Ed.) Nitel veri analizi (16-39). Ankara: PegemA.

[18] Mintzberg, H. (1973). The nature of managerial work. Harper ve Row, Publishers, Ne1w York, USA.

[19] Neuman, L.W. (2006). Toplumsal araştırma yöntemleri, (Çev. Özge, S., 2010). İstanbul: Yayın Odası.

[20] Sergiovanni, T.J. (2001). The principalship a reflective practice perspective. 4th, A Pearson Education Company Needham Heights, MA02494.

[21] Stringer, P., Hourani, R. B. (2013). Home-school relationships: a school management Perspective. Educ Res Policy Prac 12:149-174 DOI 10.1007/s 10671-012-9134-0

[22] Şişman, M. (2015). Türk eğitim sistemi ve okul yönetimi. Ankara: PegemA.

[23] Töremen, F. (2002). Eğitim örgütlerinde değişimin engel ve nedenleri. Frrat Üniversitesi Sosyal Bilimler Dergisi, Cilt: 12, Say1: 1, Sayfa: 185-202.

[24] Özdemir, S. (2000). Eğitimde örgütsel yenileşme. Ankara: PegemA Yayıncilik.

[25] Özdemir, S. (2009). Okul yöneticisi ve liderlik. S.Özdemir (Ed.), Türk eğitim sistemi ve okul yönetimi (s. 77-109). Ankara: Nobel.

[26] Yıldırım, A., Şimşek, H. (2011). Nitel araştırma yöntemleri. Ankara: Seçkin Yayıncılık.

[27] Yıldız, K. (2012). Yöneticilerin değişimi yönetme yeterlikleri. AİBÜ Sosyal Bilimler Enstitüsü Dergisi, Cilt:12, Y11:12, Say1:2, 12:177-198. 